\title{
Lectin histochemical study of the quill sebaceous gland in the dorsal skin of the Sunda porcupine (Hystrix javanica)
}

\author{
ANDHIKA YUDHA PRAWIRA ${ }^{1}$, SAVITRI NOVELINA ${ }^{1}$, WARTIKA ROSA FARIDA ${ }^{2}$, \\ HUDA SALAHUDIN DARUSMAN ${ }^{1,3}$, SRIHADI AGUNGPRIYONO ${ }^{1, \bullet}$ \\ ${ }^{1}$ Department of Anatomy Physiology and Pharmacology, Faculty of Veterinary Medicine, Institut Pertanian Bogor. Jl. Agatis, Kampus IPB Dramaga, \\ Bogor 16680, West Java, Indonesia. Tel./fax.: +62-251-8629459, "email: ysrihadi@apps.ipb.ac.id, andhikayudhaprawira60@gmail.com \\ ${ }^{2}$ Zoology Division, Research Center for Biology, Indonesian Institute of Sciences. Jl. Raya Bogor Km 46, Cibinong, Bogor 16911, West Java, Indonesia \\ ${ }^{3}$ Primate Research Center, Institut Pertanian Bogor. Jl. Lodaya II/5, Bogor 16151, West Java, Indonesia
}

Manuscript received: 29 July 2019. Revision accepted: 26 August 2019.

\begin{abstract}
Prawira AY, Novelina S, Farida WR, Darusman HS, Agungpriyono S. 2019. Lectin histochemical study of the quill sebaceous gland in the dorsal skin of the Sunda porcupine (Hystrix javanica). Biodiversitas 20: 2677-2684. In the Sunda Porcupine skin, the sebaceous glands of the quill follicles are multi-lobed alveolar and better developed than those of hair follicles. Using lectin histochemistry, we have studied the distribution of sugar-binding in the sebaceous glands of quills in comparison with those of hairs in six adult Sunda Porcupines. The skin samples from the thoracodorsal and lumbosacral regions were collected by biopsy procedure and processed for histology, histochemistry, and lectin histochemistry. The results showed that the lectin binding patterns are similar in secretory acinar parts of both types of sebaceous glands. The acini and excretory duct contained neutral carbohydrate and sugar residues. The acini also contained alpha D-mannose sugar residue, while the non-secretory excretory duct and debris in the lumen contained alpha-D-mannose, alpha-L-fucose, and $\alpha>\beta$-N-acetylgalactosamine, and complex type N-glycan (oligosaccharide) sugar residues, as well. The present findings allowed us to suggest, that in Sunda Porcupine functions of the sebaceous glands of quills are more complex and active compared to those of the hairs.
\end{abstract}

Keywords: Acini, excretory duct, hairs, quills, sebaceous glands, sugar residue

\section{INTRODUCTION}

It is well known for some mammal species, that carbohydrates and glycoconjugates are present in secretory part of specialized sebaceous glands, such as the infraorbital glands of the barking deer males Muntiacus muntjak (Adnyane et al. 2011), the intermandibular gland of the lesser mouse-deer Tragulus javanicus (Agungpriyono et al. 2006), the interdigital and preputial glands of the Japanese serow Capricornis crispus (Atoji et al. 1988; 1989), and the glands of human skin (Wollina et al. 1989). Most of sebaceous glands are associated with hair follicles and secrete the sebum to lubricate fur, and haired skin (Pochi 1982). In humans, the sebaceous glands display a strong reaction to wheat germ agglutinin (WGA) and concanavalin agglutinin (ConA) in peripheral acinar and infundibular cells, while enlarged central sebocytes have the weaker reactions (Wollina et al. 1989). This pattern suggests that the glycan plays specific role in lipogenesis (Atoji et al. 1989). Several studies exhibit that glycogen particles are distributed in the cytoplasm of human and mammalian sebaceous glands (Bell 1974; Jenkinson et al. 1985).

The determination of the glycoconjugates' patterns can be performed by labeling their available carbohydrate residues with lectins (Sharon and Lis 1975). Using histochemistry of lectin, presence of specific sugar residues is demonstrated in sebaceous and apocrine glands associated with hairs (Tsukise and Meyer 1983; Ookusa 1984; Tsukise et al. 1985).

The Sunda Porcupine (Hystrix javanica F. Cuvier, 1823) (further the porcupine) is an endemic Indonesian rodent, and member of the Hystricidae family. These wild porcupines inhabit Java, Bali, Madura, Sumbawa, Flores, Lombok and Tonahdjampea islands (van Weers 1979). As other porcupine species, it has specific thick and long quills, which differ from short and thinner spines of most mammal species. The quills of all porcupine species are larger, stiffer and stronger than its hairs and act as means of self-defense from predators or other threats (Mohr 1965; Myers 2001; van Weers 1983). Previously we exhibit that the appearances of dorsal skin surface of the porcupine is wavy due to protrusion of quill follicles in the form of clusters and varying in size according to the location and quill type (Prawira et al. 2018b). The quill follicles are known as the dominant structure in the skin of this species (Prawira et al. 2018a). In addition, the porcupine dorsal skin lacked sweat glands, while sebaceous glands lie under the orifices of hair's and quill's follicles. Sizes of the sebaceous glands of quills were relatively larger compared to the hairs' glands. Glandular lobules of quill sebaceous gland were composed of well-developed sebaceous acinar cells with lipid vacuoles varying in size (Prawira et al. 2018b).

Although we know several studies of lectin binding in sebaceous glands, all glands studied are specific skin organs (infraorbital, interdigital, preputial glands) which 
have specific topography and structure. Studies of lectinbinding in the sebaceous glands of hair follicles, conducted by Wollina et al. (1989), are devoted to human hairs, however, in the porcupine, size of quills and its follicular structure are quietly different compared to the hair follicles. That is why, in the present study, we examined the standard carbohydrate staining and lectin histochemistry in order to investigate the distribution and pattern of glycoconjugatebinding site in the sebaceous glands of two different types - hairs' glands and quills' glands.

\section{MATERIALS AND METHODS}

\section{Animals and histology processing}

We used six adult porcupines (three individuals of each sex) weighing 6-8 kg. All procedures were performed in accordance with the ethical approval of The Ethical Clearance Subcommittee of Life Science, Indonesian Institute of Sciences, No. B-12695/K/KS.02.04/XII/2017. These porcupines were sampled by skin biopsy and the procedures were conducted under anesthesia $(10 \% \mathrm{HCl}$ ketamine and $2 \%$ Xylazine $\mathrm{HCl}$ with a dose of $2.5 \mathrm{mg} / \mathrm{kg}$ $\mathrm{BW}$ and $1 \mathrm{mg} / \mathrm{kg} \mathrm{BW})$. The skin biopsy samples were taken from two dorsal regions - - thoracodorsal (TD) and lumbosacral (LS).

These samples were fixed in $10 \%$ buffer neutral formalin (BNF) for seven days. They underwent a standard paraffin histological procedure. The paraffin blocks were cut serially at $5 \mu \mathrm{m}$ of thickness and the sections were stained by several methods. The hematoxylin and eosin staining method was performed to evaluate the general structure, and also with periodic acid Schiff-reaction (PAS), and Alcian blue (AB) pH 2.5 method to evaluate the neutral and acid carbohydrates. The data obtained were analyzed descriptively.

\section{Lectin histochemistry staining}

Dewaxed sections were incubated with $0.3 \% \mathrm{H}_{2} \mathrm{O}_{2}$ in methanol for $10 \mathrm{~min}$ at room temperature and then washed with Tris- $\mathrm{HCl}$ Buffer $\mathrm{pH} 7.58$ containing $2 \%$ normal goat serum for $30 \mathrm{~min}$ at $37{ }^{\circ} \mathrm{C}$. The sections were then incubated overnight at $4{ }^{\circ} \mathrm{C}$ with six biotinylated lectins (Table 1) (Vector Lab. Inc. Burlingame, USA). The sections were washed with Tris- $\mathrm{HCl}$ Buffer $\mathrm{pH} 7.58$ and incubated with an ABC (Avidin-Biotin Complex) kit (PK6100, Vector Lab. Inc. Burlingame, USA) for $30 \mathrm{~min}$ at 37
${ }^{\circ} \mathrm{C}$. Visualization of the reaction product was performed by incubation in 3,3ф- diaminobenzidine for 2 minutes. Sections were counterstained with hematoxylin Gill III, and dehydrated in graded ethanol, cleared in xylene and mounted with Entellan ${ }^{\circledR}$. They were observed under the light microscope (Olympus CX 31, Japan) and compared the intensity by a qualitative scoring graded as negative (-), very weak $(+)$, weak $(++)$, moderate $(+++)$, strong $(++++)$, very strong $(+++++)$. In the present study, we used small intestine sections from same species as the positive control. Subsequently, the negative controls were skin sections with Tris- $\mathrm{HCl}$ buffer treatment as the substitute of lectins. The data were analyzed descriptively.

\section{RESULTS AND DISCUSSION}

\section{Carbohydrate contents}

The sebaceous glands (further glands) of quills of the porcupine were large and composed of many lobes and excretory ducts (Figure 1). The wall of duct was lined with the keratinized and stratified epithelium and became thinner, about 1-2 cells of thickness in the acinar part. Additionally, the lobes and ducts contained sebocytes at various stage of development (Figures 2 and 3). In contrast to the gland of quill, the glands of hairs are very small and are composed of only a few small acini (Figure 1 to Figure 3 ). In this study, the glands of hairs were not observed in complete structure due to their small size. The lumen and the wall of the excretory duct were not observed well.

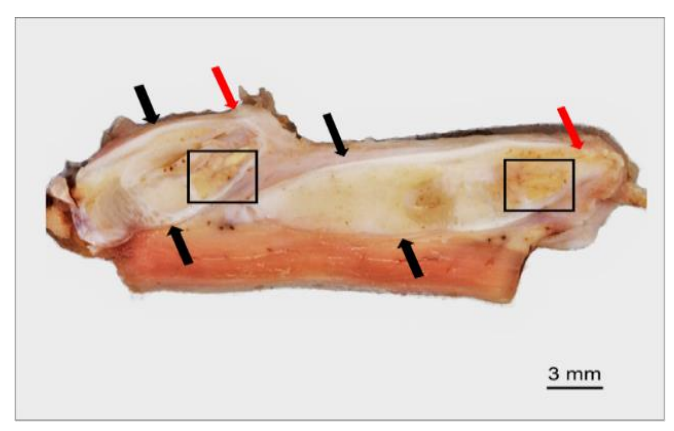

Figure 1. General view of inner skin side of the Sunda Porcupine. Quill follicles are shown by black arrows; hair follicles - by red arrows; location of sebaceous glands of quills is inside of black box

Table 1. List of lectin

\begin{tabular}{|c|c|c|c|}
\hline Lectin & Acronym & Specificity & $\begin{array}{c}\text { Concentration } \\
(\mu \mathrm{g} / \mathrm{mL})\end{array}$ \\
\hline Concanavalin agglutinin & ConA & $\alpha$-D-Man, $>\alpha$-D-Glc & 10 \\
\hline Ulex europaeus agglutinin I & UEA & $\alpha$-L-Fuc & 20 \\
\hline Soybean agglutinin & SBA & $\alpha>\beta$ GalNAc & 10 \\
\hline Phaseolus vulgaris erythroagglutinin & PHA-E & $\begin{array}{l}\text { Gal } \beta 4 G l c N A c \beta 2 M a n \alpha 6(G l c N A c \beta 4) \\
\text { (GlcNAc } \beta 4 M a n \alpha 3) M a n \beta 4 \text { - (Oligosaccharide) }\end{array}$ & 15 \\
\hline Phaseolus vulgaris leucoagglutinin & PHA-L & $\begin{array}{l}\text { Gal } \beta 4 \text { GlcNAc } \beta 6(\text { GlcNAc } \beta 2 M a n \alpha 3) M a n \alpha 3 \\
\text { (Oligosaccharide) }\end{array}$ & 15 \\
\hline Dolichos biflorus agglutinin & DBA & $\alpha-D-N-G a l N A c$ & 20 \\
\hline Succynilated Wheat Germ Agglutinin & SWGA & GlcNAc & 15 \\
\hline
\end{tabular}


Table 2. Carbohydrate and lectin-binding pattern in sebaceous glands of quills and hairs of the Sunda Porcupine

\begin{tabular}{|c|c|c|c|c|c|c|}
\hline \multirow{3}{*}{ Stain } & \multicolumn{6}{|c|}{ Sebaceous Gland } \\
\hline & \multicolumn{2}{|c|}{ Acini } & \multicolumn{2}{|c|}{ Duct } & \multicolumn{2}{|c|}{ Lumen } \\
\hline & HF & QF & HF & QF & HF & $\mathbf{Q F}$ \\
\hline PAS & $-\sim+$ & $-\sim+$ & + & +++ & - & - \\
\hline $\mathrm{AB}$ & - & - & - & - & - & - \\
\hline \multicolumn{7}{|l|}{ Lectin } \\
\hline ConA & $+++\sim++++$ & $++\sim+++$ & $\mathrm{N} / \mathrm{O}$ & ++++ & $\mathrm{N} / \mathrm{O}$ & ++ \\
\hline UEA & $-\sim+$ & - & $\mathrm{N} / \mathrm{O}$ & ++ & $\mathrm{N} / \mathrm{O}$ & + \\
\hline SBA & - & - & N/O & + & $\mathrm{N} / \mathrm{O}$ & + \\
\hline PHA-E & - & $-\sim+$ & $\mathrm{N} / \mathrm{O}$ & $-\sim+$ & N/O & + \\
\hline PHA-L & - & - & $\mathrm{N} / \mathrm{O}$ & $-\sim+$ & $\mathrm{N} / \mathrm{O}$ & $-\sim+$ \\
\hline DBA & - & - & $\mathrm{N} / \mathrm{O}$ & - & N/O & - \\
\hline SWGA & - & - & $\mathrm{N} / \mathrm{O}$ & - & $\mathrm{N} / \mathrm{O}$ & - \\
\hline
\end{tabular}

HF: sebaceous glands of hairs, QF: the same of quills; -: negative, - +; very weak, +: weak, ++: moderate, +++: strong, ++++: very strong, N/O: Not Observed

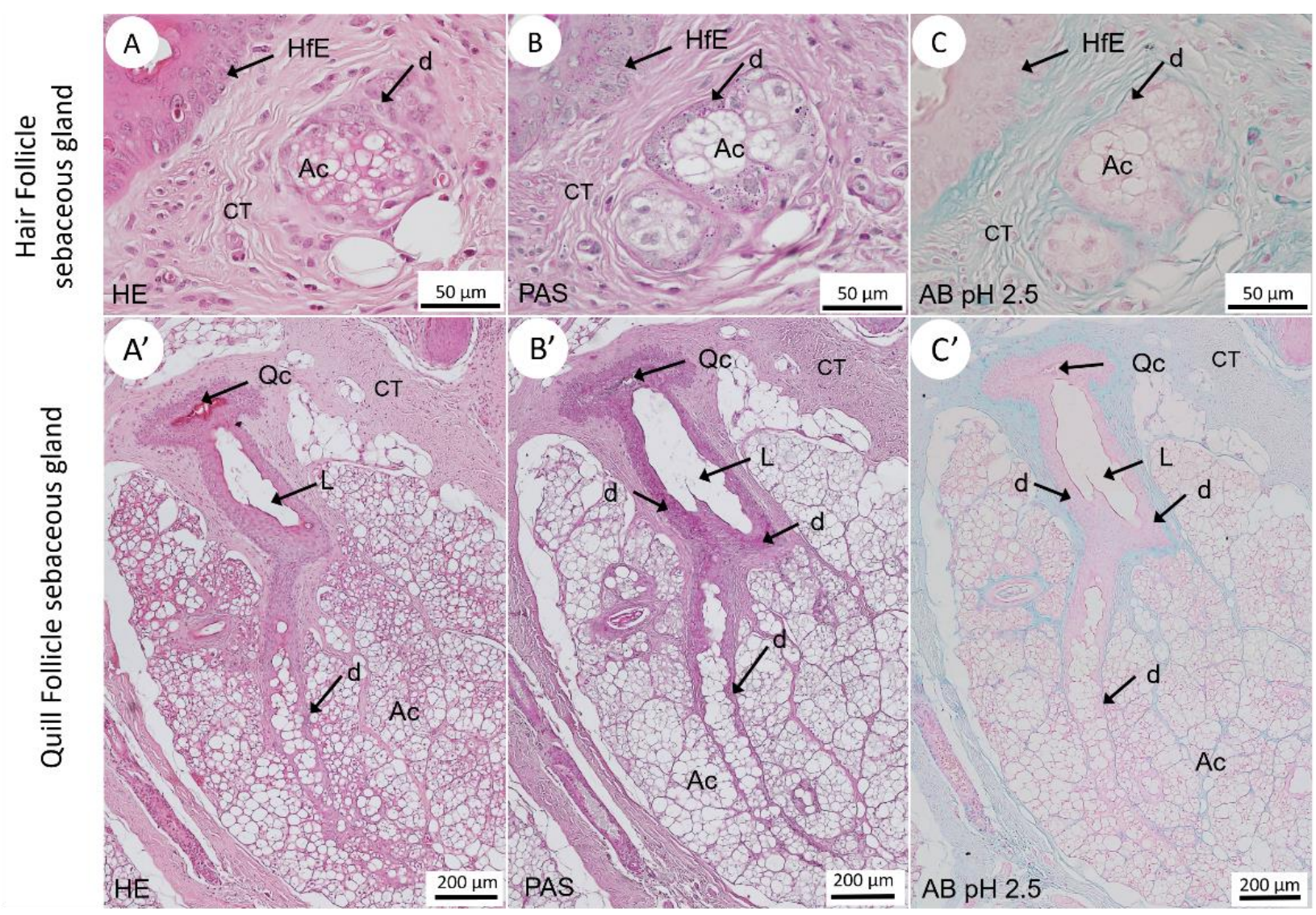

Figure 2. Comparison of carbohydrate distribution patterns in the sebaceous gland of a hair follicle (A, B, C) and a quill follicle (A', B', C'). Neutral carbohydrates' distribution (B, B') when PAS staining showed their limited distribution in the upper part of excretory duct and peripheral sebocytes in the acini. Distribution of acid carbohydrates (C, C') in the sebaceous glands. Only the connective tissue of the glands reacted, while other parts of the gland demonstrated no positive reaction. (L: lumen, d: excretory duct, CT: connective tissue, HfE: epidermis of hair follicle, Qc: quill canal, Ac: acini). Transversal sections. Photomicrographs

The result of PAS staining showed numerous neutral carbohydrates contained in the various parts of the gland (Table 2). Neutral carbohydrates were scattered abundantly in a wall of quill follicle canal and excretory duct of a gland if compared to those of a hair follicle (Figure 3). Moreover, the peripheral (lying on the membrane) sebocytes were PAS-positive in both types of glands (Figure 1). In contrast, $\mathrm{AB} \mathrm{pH} 2.5$ was negative both in the quill and hair glands (Figures 2 and 3). A positive reaction for $\mathrm{AB}$ was observed in the connective tissue around the glands (Figures 2 and 3). No differences were observed between the TD and LS regions. 


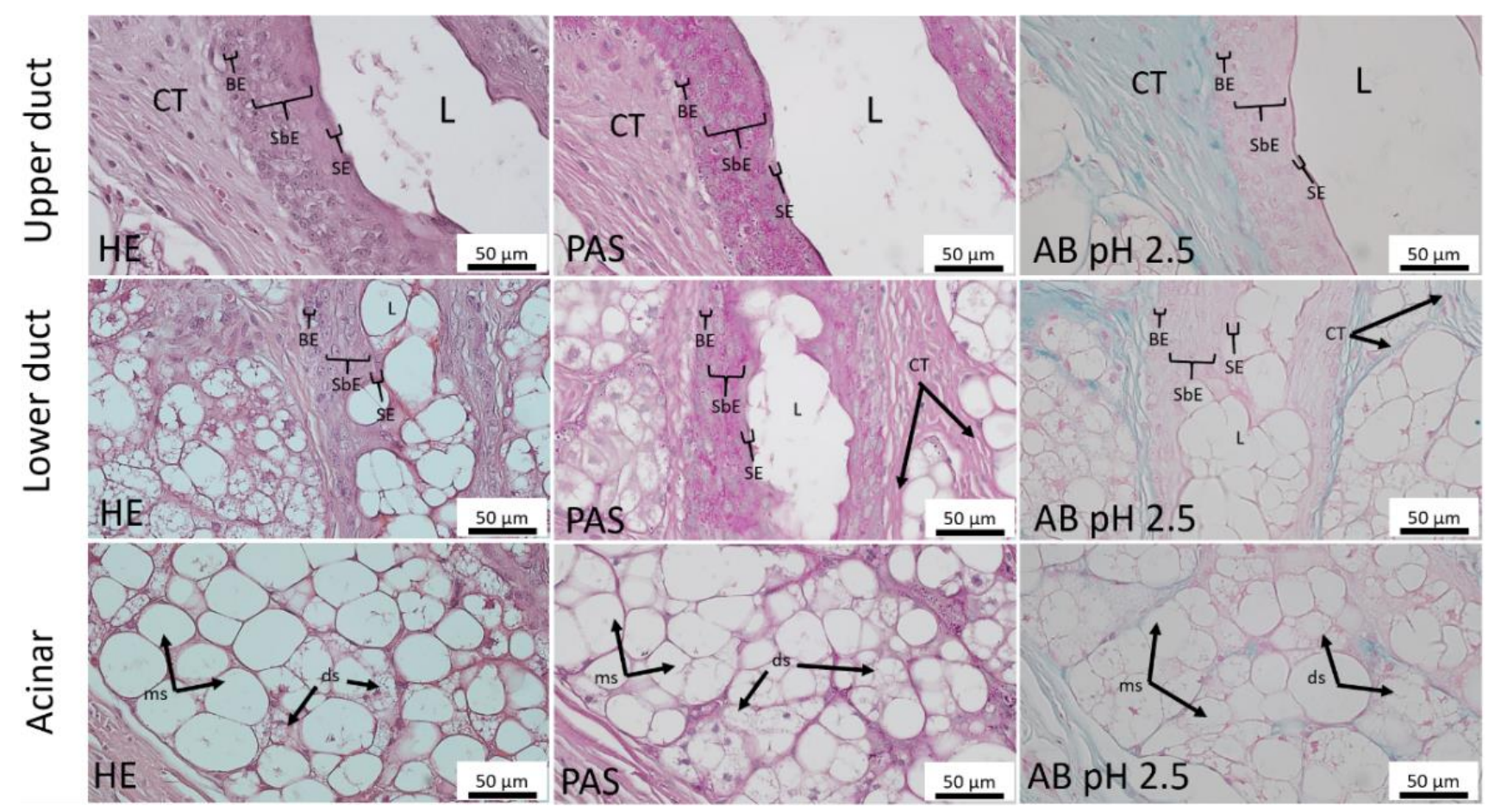

Figure 3. The sebaceous gland of quill follicle at higher magnification. Neutral carbohydrates' content in PAS staining was distributed abundantly in the excretory duct (upper and lower duct), while the acinar part weakly reacted in the peripheral sebocytes. Acid carbohydrates' content when $\mathrm{AB}$ staining was only distributed in connective tissue around and inside the gland. (L: lumen, BE: basal epithelium, SbE, suprabasal epithelium, SE: superficial epithelium, CT: connective tissue, ms: mature sebocytes, ds: developing sebocytes). Transversal sections. Photomicrographs
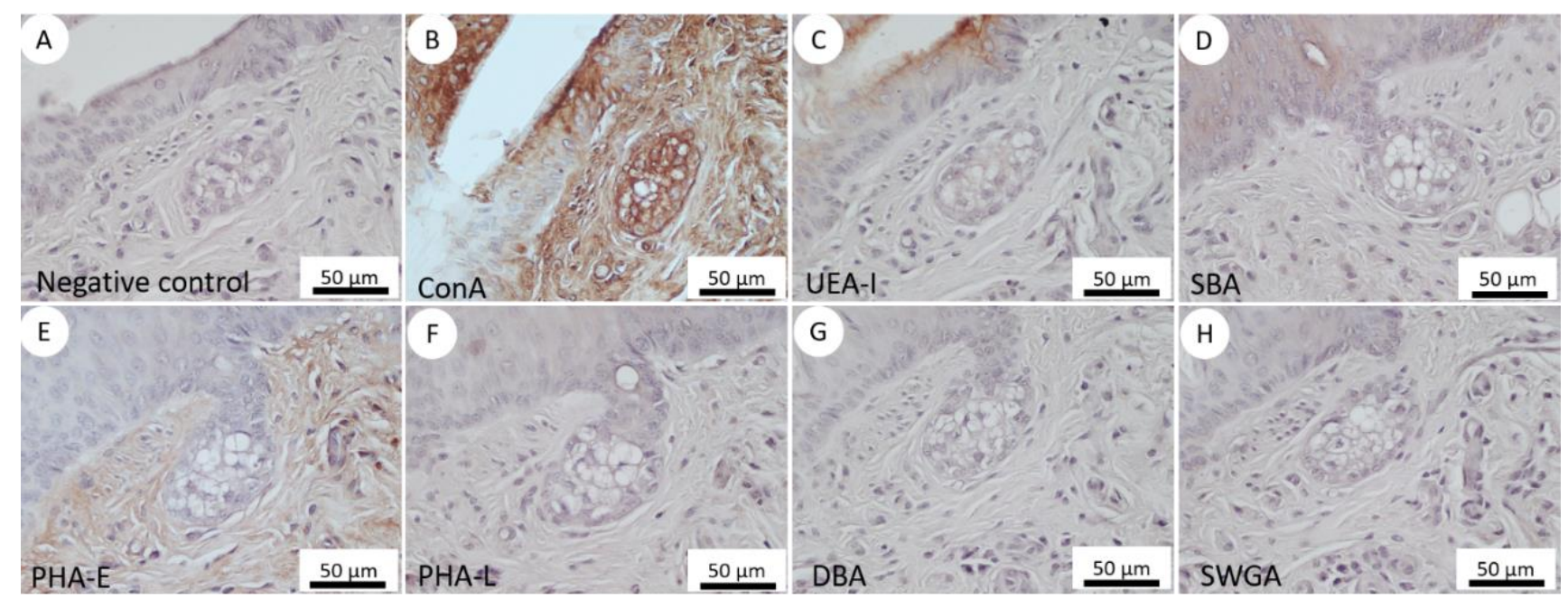

Figure 4. The lectin binding reaction in the sebaceous gland of hair follicle. The reaction of ConA in all parts of the gland was strong compared to all lectin. The UEA and SBA exhibited weak to moderate positive reaction in acini and epithelium of hair follicle. PHA-E binding showed distributed in the connective tissue only. The PHA-E, PHA-L, DBA and SWGA presented no reaction in the gland. Transversal sections. Photomicrographs

\section{Lectin-binding distribution}

The glands showed positive reaction in five out of seven lectins used in this study. Con-A, UEA, SBA, PHA$\mathrm{E}$ and PHA-L were positive with various intensities in several parts of the gland -- acini, excretory duct and connective tissue (Figures 4 and 6). No positive reaction in the gland was observed for other lectins, DBA and SWGA (Table 2). The lectin binding pattern in the gland of hair was only observed in the acinar part due to its small size (Figure 3). The lectin binding pattern was similar to the gland of quill with slight differences in ConA and UEA-I binding in the acini (Table 2). No differences were 
observed between the TD and LS regions. In present study, we found that ConA binding intensity in male quill gland is slightly stronger than those of female.

Con-A which represents $\alpha$-D-mannose sugar residue, displayed affinity in almost part of the gland -- canal of quill follicle, excretory duct, lobes of acini. Strong affinity was observed in the canal of quill follicle and in the excretory duct, while the secretory part, the acini, showed moderate to strong affinity. The epithelium of the canal and excretory duct showed reactivity in the cytoplasm and peripheral cells and keratinocytes in the basal (stratum basalis), suprabasal (stratum spinosum) and superficial (stratum granulosum and stratum corneum) epithelium (Figure 6). Meanwhile, the acini showed various reactivity in the membrane and lipid vacuoles of sebocytes. The developing sebocytes indicated strong affinity, while enlarged and matured sebocytes displayed decreased affinity to moderate. In addition, the debris found in the lumen of the excretory duct was positive to Con-A (Figure $6)$.

UEA and SBA presented affinity in the non-secretory part of the gland, which was the canal of quill follicle and excretory duct (Figure 6). In general, the affinity of UEA was stronger than SBA (Table 2). Both UEA and SBA presented positive affinity in the suprabasal and superficial layer of the epithelium. The affinity was stronger in the upper part, but weaker in the lower part of excretory duct (Figure 6). The debris in the lumen of the duct also reacted to the lectins (Table 2). The affinity of UEA and SBA to the excretory duct indicated that the duct contained $\alpha-\mathrm{L}$ fucose and $\alpha, \beta-\mathrm{N}$-acetylgalactosamine sugar residues.

PHA-E showed positive binding reaction in the connective tissue of the skin, including the fiber in the gland and peripheral sebocytes, while PHA-L binding reaction was positive in a small part of the excretory duct only. Superficial layer of the epithelium in the excretory duct and debris in the lumen were weakly positive to PHA$\mathrm{E}$ and PHA-L binding (Figures 5 and 6).

\section{Discussion}

Mainly, the sebaceous glands are usually associated with hair follicles (Montagna 1974). Quills and spines are structural modification of the hairs, which are found in some mammals, including porcupines, spiny mouse and rats, hedgehogs, tenrecs and echidnas (van Weers 1979, 1983; Zherebtsova 2000). Previous research on Hystrix javanica and Erethizon dorsatum, the new world porcupine, revealed that the sebaceous glands are also associated with the quill follicles, and have a larger size than those of the hair follicle (Prawira et al. 2018b; Chapman and Roze 1997). This suggests that the function of the glands to lubricate quills is greater than that of sebaceous glands in hair follicles.

The sebaceous gland is developed from the epithelial layer of the epidermis in the hair follicle called the pilosebaceous unit. The excretory duct is composed of a layered and keratinized epithelium, which originates from the outer root sheath (ORS) of the hair follicle (Knutson 1974). Thus, the characteristic of ORS cells is still found in the excretory duct epithelium of the sebaceous gland of hair follicles, which represents the presence of abundant glycogen droplets (Parakkal 1969). Similar structures and patterns of neutral carbohydrates' distribution in the excretory duct were found in the Sunda Porcupine sebaceous glands of quills follicle. In contrast, although acid carbohydrates' content can be detected in several parts of the sebaceous glands, such as pig's eyelid gland (Yasui et al. 2006), the presence of acid carbohydrates was not observed in the quill gland of the porcupine in the present study.

The process of sebaceous gland secretion involves the regeneration and differentiation of peripheral cells in sebocytes containing lipids (Montagna 1974; Thody and Shuster, 1989). A sebaceous gland in a human pilosebaceous unit is known to changes in the character of glycoconjugates. Enlarged and matured sebocytes in the center of the acinar area have decreased glycoconjugate intensity compared to peripheral regions (Wollina et al. 1989). The pattern suggested that glycan plays a role in sebocytes' development and maturation, especially in lipogenesis (Atoji et al. 1989). In present study, such pattern was also found in the gland of quill of the porcupine.

Alpha D-Mannose is found in various glycoconjugates (Mersmann et al. 1976). Mannose is known as the main monosaccharide component in $\mathrm{N}$-glycans and relies on the availability of Mannose-6-Phosphate, Mannose-1Phosphate, Guanosine diphosphate mannose, and dolichos phosphate mannose for synthesis of lipid-linked oligosaccharides (Sanyal and Menon 2009; Aebi 2013). This is might be the reason for the wide distribution of Con-A affinity in sebaceous glandular tissue. L-fucose is a monosaccharide that is often a component of many $\mathrm{N}$ - and O-linked glycans and glycolipids produced by mammalian cells (Moloney and Haltiwanger 1999). Alpha-L-Fucose is known to be found in the differentiated epidermal layer, st. spinosum and st. granulosum (Nemanic et al. 1983). The presence of this sugar glycan in the excretory duct of sebaceous glands might be indicated to play a role in differentiation of the epidermal cells since the excretory duct originates from the ORS of a pilosebaceous unit (similar to the quill follicle in the Sunda Porcupine skin). The presence of $\mathrm{N}$-acetylgalactosamine in the glandular duct epithelium is thought to play a role in the attachment between keratinocytes (Tenno et al., 2007; Brockhausen et al. 2009).

The lumen of excretory duct and center portion of the matured sebocytes generally contain lipids, cell fragments, fragments of keratinocytes and microorganisms (Montagna 1974), resulting in some parts reacting positively with lectins. Alpha D-Mannose, L-fucose and NAcetylgalactosamine, which present in the lumen of the excretory duct of glands of quills of the porcupine, are known as a part of glycoprotein, which can inhibit the adherence of some bacteria and fungi to the surface epidermal cells (Sharon et al. 1981; McGavin et al. 1993; Ollert et al. 1993; Critchley and Douglas 1987). 

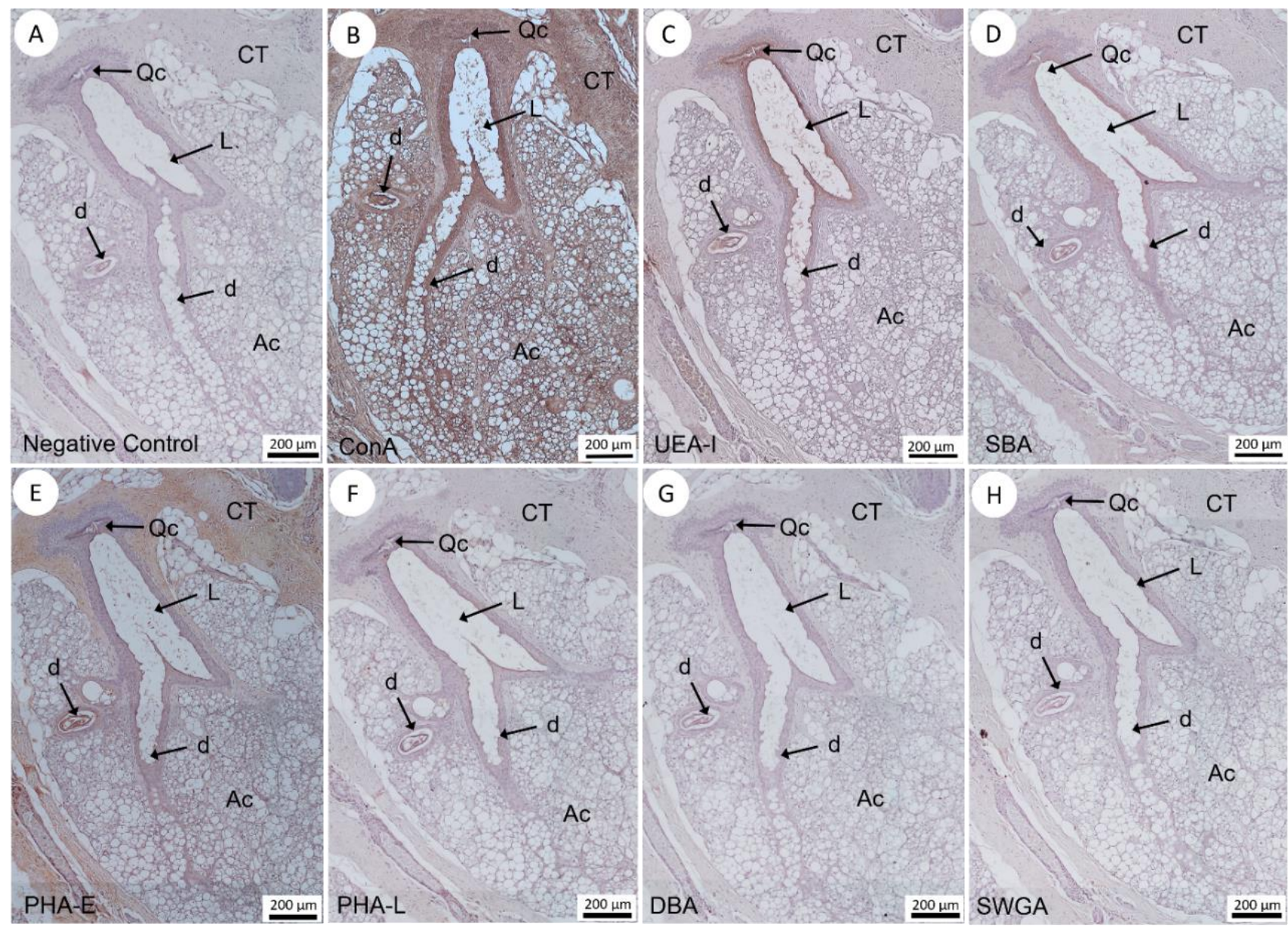

Figure 5. Lectin binding reaction in the sebaceous gland of quill follicle. ConA lectin presented strongly to very strong reaction in all parts of the gland, while UEA and SBA showed positive reaction in epithelium of excretory duct. PHA-E and PHA-L lectin exhibited a positive reaction in the lumen and superficial part of the excretory duct. In addition, PHA-E lectin also displayed strong positive reaction in connective tissue around and in the gland. DBA and SWGA had negative reaction (Qc: Quill canal, d: excretory duct, Ac: acini of the gland, CT: connective tissue). Transversal sections. Photomicrographs

PHAE and PHAL are the lectins, which bind specifically for oligosaccharide of complex-type N-glycan (Hirabayashi et al. 2011; Gabius et al. 2011). A role of complex type $\mathrm{N}$-glycan for glands' secretory activity remains unclear, especially for the sebaceous glands, although some of its functions had been already studied, such as regulation of cellular proliferation and differentiation (Lau et al. 2007), communication between cell and matrix (Leahy et al. 1996; Hynes 2002; Nagae et al. 2012), and controlling of assembly and stabilization of the protein complexes in the adaptive immune system (Rudd et al. 1999).

Several studies of a specialized gland which contained sebaceous part, such as infraorbital gland of the male barking deer (Adnyane et al. 2011) and scent gland of the Syrian hamster and the Mongolian gerbil (Aoki-Komori et al. 1994) showed that the gland was positive with many lectins, such as Con-A, RCA-I, PNA, SBA, UEA-I, DBA, and WGA. The distribution of these sugar residues may play an important role in territorial marking, and play a vital role in the production of odoriferous signals for animals' communication, as well (Aoki-Komori et al. 1994; Adnyane et al. 2011). Such distribution was not observed in sebaceous glands of the porcupine quills in even though the size of glands is large. The lectin binding pattern in sebaceous gland of Sunda Porcupine was thought to play a role in coating the skin and quill, as well as to protect the skin surface from the environmental exposure, such as microorganisms, dust, etc.

The difference in intensity between male and female might be influenced by different hormonal activity between the sexes which affecting the activity of the sebaceous glands (Cunliffe and Forster 1987; Fritsch et al. 2001). A study by Strauss et al. (1962) reveals that estrogen in female shows inhibition of the activity of the in vivo sebaceous glands. 

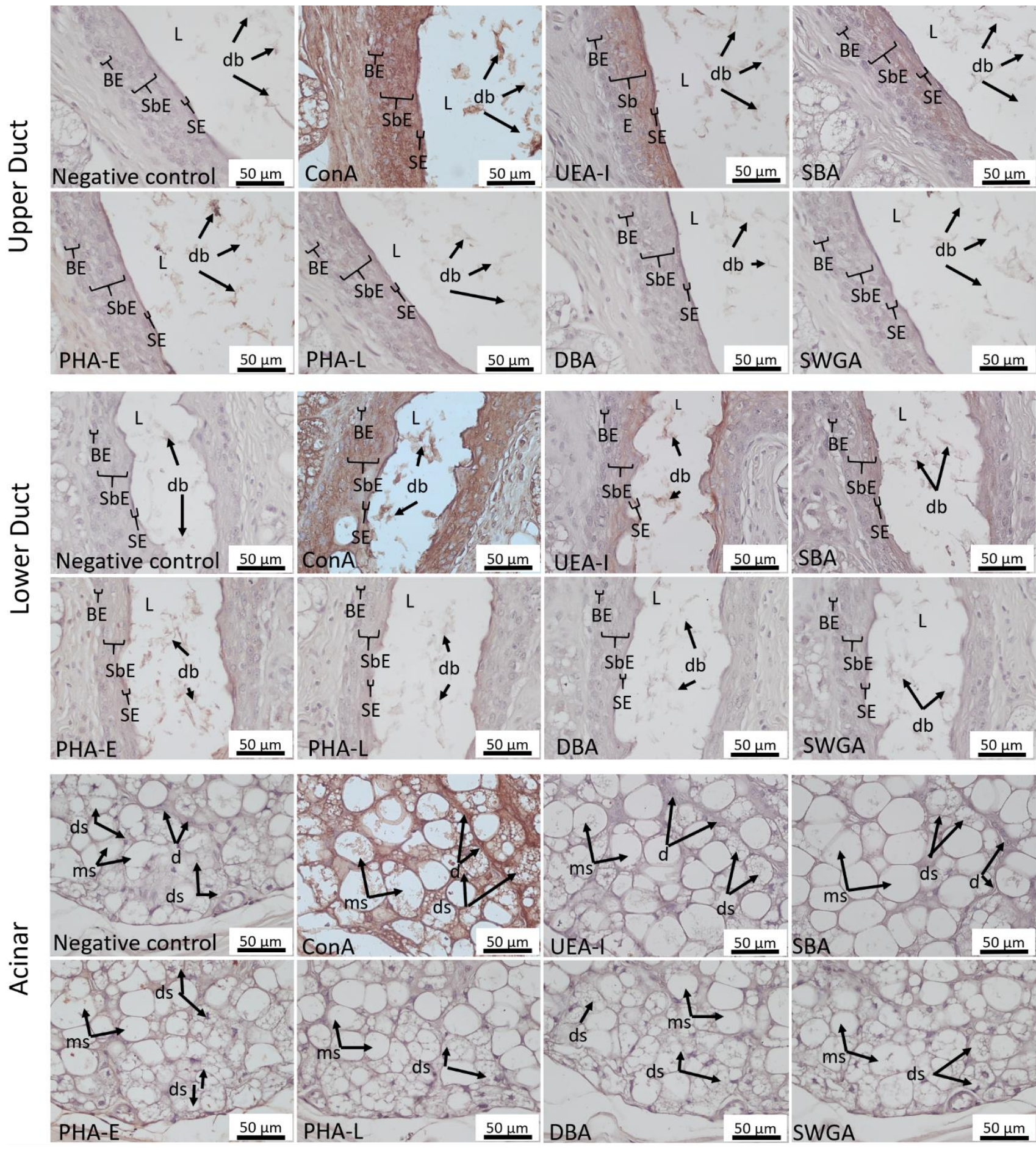

Figure 6. Lectin binding in the excretory duct (upper and lower part) and acinar of the sebaceous gland. ConA lectin presented a strong to very strong reaction in the epithelium, lumen, and sebocytes, while UEA-I and SBA showed a weak to moderate reaction. PHA-E and PHA-L displayed a very low to low reaction in the epithelium and lumen, while DBA and SWGA had no reaction. The other lectin (UEA-I, SBA, PHA-L, DBA, SWGA) showed no positive reaction in acinar. (L: lumen, BE: basal epithelium, SbE, suprabasal epithelium, SE: superficial epithelium, db: debris, ms: mature sebocyte, ds: developing sebocyte). Transversal sections. Photomicrographs

In conclusion, the present findings on the distribution and intensity of lectin bindings might suggest a complex and active function of the sebaceous glands of quill follicles compared to those of the hair follicles in the Sunda Porcupine. The significance and function of alpha-DMannose, alpha L-fucose, $\alpha>\beta-\mathrm{N}$-Acetylgalactosamine and complex type $\mathrm{N}$-glycan sugar residues in the sebaceous glands of quill follicles remain to be clarified in future studies. Additionally, these findings presented the type and distribution of sugar residues in the sebaceous glands of the quills. 


\section{ACKNOWLEDGEMENTS}

The study was partly supported by the Ministry of Research, Technology and Higher Education of the Republic of Indonesia through PMDSU (Pendidikan Magister menuju Doktor untuk Sarjana Unggul) scholarship program No. 1468/IT3.11/PN/2018.

\section{REFERENCES}

Adnyane IKM, Zuki AB, Noordin MM, Wahyuni S, Agungpriyono S. 2011. Morphological study of the infraorbital gland of the male barking deer, Muntiacus muntjak. Afr J Biotechnol 10(77): 1789117897.

Aebi M. 2013. N-linked protein glycosylation in the ER. Biochim Biophys Acta 1833: 2430-2437

Agungpriyono S, Atoji Y, Yamamoto Y, Zuki AB, Novelina S. 2006. Morphology of the intermandibular gland of the lesser mouse deer, Tragulus javanicus. Anat Histol Embryol 35: 325-333.

Aoki-Komori S, Saito TR, Umeda M, Sugiyama M, Takahashi KW, Taniguchi K. 1994. Lectin histochemical studies on the scent gland in the Syrian hamster and Mongolian gerbil. Jikken Dobutsu 43: 181190.

Atoji Y, Suzuki Y, Sugimura M. 1989. The preputial gland of the Japanese serow (Capricornis crispus): ultrastructure and lectin histochemistry. Acta Anat 134: 245-252.

Atoji Y, Suzuki Y, Sugimura M. 1988. Lectin histochemistry of the interdigital gland in the Japanese serow (Capricornis crispus) in winter. J Anat 161:159-170

Bell M. 1974. A comparative study of the ultrastructure of the sebaceous glands of man and other primates. J lnvest Dermatol 62: 132-143.

Brockhausen I, Schachter H, Stanley P. 2009. O-GalNAc Glycans. In Varki A, Cummings RD, Esko JD, Freeze HH, Stanley P, Bertozzi CR, Hart GW, Etzler ME (eds). Essentials of Glycobiology, 2nd edition. Cold Spring Harbor Laboratory Press, New York.

Chapman DM, Roze U. 1997. Functional histology of quill erection in the porcupine, Erethizon dorsatum. Can J Zool 75: 1-10.

Critchley IA, Douglas LJ. 1987. Role of glycosides as epithelial cell receptors for Candida albicans. J Gen Microbiol 133: 637-643.

Cunliffe WJ, Forster RA. 1987. Androgen control of the pilosebaceous duct. Br J Dermatol 116(3): 449-449.

Fritsch M, Orfanos CE, Zouboulis CC (2001) Sebocytes are the key regulators of androgen homeostasis in human skin. J Invest Dermatol 116:793-800

Gabius HJ, André S, Jiménez-Barbero J, Romero A, Solís D. 2011. From lectin structure to functional glycomics: principles of the sugar code. Trends Biochem Sci 36(6): 298-313.

Hirabayashi J, Kuno A, Tateno H. 2011. Lectin-based structural glycomics: A practical approach to complex glycans. Electrophoresis 32(10): 1118-1128.

Hynes RO. 2002. Integrins: Bidirectional, allosteric signaling machines. Cell 110: 673-687.

Jenkinson DM, Elder HY, Montgomery L, Moss VA. 1985. Comparative studies of the ultrastructure of the sebaceous gland. Tissue Cell 7: 983-698.

Knutson DD. 1974. Ultrastructural observations in acne vulganis: the normal sebaceous follicle and acne lesions. J lnvest Dermatol 62: 288-307.

Lau KS, Partridge EA, Grigorian A, Silvescu CI, Reinhold VN, Demetriou M, Dennis JW. 2007. Complex N-glycan number and degree of branching cooperate to regulate cell proliferation and differentiation. Cell 129: 123-134.

Leahy DJ, Aukhil I, Erickson HP. 1996. 2.0 ̊ crystal structure of a fourdomain segment of human fibronectin encompassing the RGD loop and synergy region. Cell 84: 155-164.

McGavin MH, Krajewska-Pietrasik D, Ryden C, Hook M. 1993. Identification of a Staphylococcus aureus extracellular matrix-binding protein with broad specifity. Infect Immun 61: 2479-2485.

Mersmann G, von Figura K, Buddecke E. 1976. Storage of mannosecontaining material in cultured human mannosidosis cells and metabolic correction by pig kidney alpha-mannosidase. HoppeSeyler's Zeitschrift fur Physiologische 357: 641-648.
Mohr E. 1965. Altweltliche Stachelschweine. A. Ziemsen Verlag [Eds.], Wittenburg Lutherstadt, Germany.

Moloney DJ, Haltiwanger RS. 1999. The O-linked fucose glycosylation pathway: identification and characterization of a uridine diphosphoglucose: fucose-beta1,3-glucosyltransferase activity from Chinese hamster ovary cells. Glycobiology 9: 679-687.

Montagna W. 1974. An introduction to sebaceous gland. J lnvest Dermatol 62: 120-123.

Myers P. 2001. "Hystricidae" (on-line), Animal Diversity Web. Accessed September 12, 2015 at http://animaldiversity.org/accounts/hystricidae.

Nagae M, Re S, Mihara E, Nogi T, Sugita Y, Takagi J. 2012. Crystal structure of $\alpha 5 \beta 1$ integrin ectodomain: Atomic details of the fibronectin receptor. J Cell Biol 197: 131-140.

Nemanic MK, Whitehead JS, Elias PM. 1983. Alteration in membrane sugars during epidermal differentiation: visualization with lectin and role of glycosidases. J Histochem Cytochem 31(7): 887-897.

Ollert MW, Söhnchen R, Korting HC, Ollert U, Bräutigam S, Bräutigam W. 1993. Mechanism od adherence of Candida albicans to cultured human epidermal keratinocytes. Infect Immun 61: 4560-4568.

Ookusa Y. 1984. Histochemical studies of lectin binding pattern in human skin. I. Lectin binding pattern in normal human skin. Jpn J Dermatol 94: 1155-1163.

Parakkal PF. 1969. The fine structure of anagen hair follicle of the mouse. Adv Skin Biol 9: 441-469.

Pochi P. 1982. The sebaceous gland. In: Maibach HI, Boisits EK (eds), Neonatal Skin: Structure and Function. Marcel Dekker, New York.

Prawira AY, Hanadhita D, Rahma A, Supratikno, Novelina S, Agungpriyono S. 2018a. Characteristic of skin morphology of Sunda porcupine (Hystrix javanica) with special reference to the connective tissue. Indon J Vet Sci 12(1): 23-28

Prawira AY, Novelina S, Darusman HS, Farida WR, Agungpriyono S. 2018b. The dorsal skin structure contributes to the surface bacteria populations of Sunda Porcupine (Hystrix javanica). Anat Histol Embryol 47: 591-598.

Rudd PM, Wormald MR, Stanfield RL, Huang M, Mattsson N, Speir JA, DiGennaro JA, Fetrow JS, Dwek RA, Wilson IA. 1999. Roles for glycosylation of cell surface receptors involved in cellular immune recognition. J Mol Biol 293: 351-366.

Sanyal S, Menon AK. 2009. Specific transbilayer translocation of dolichol-linked oligosaccharides by an endoplasmic reticulum flippase. Proc Nat Acad Sci United States Am 106: 767-772

Sharon N, Lis H. 1975. Use of lectins for the study of membranes. In: Methods in Membrane Biology (Edited by Korn E.) Vol. 3. pp. 147200. Plenum Press, New York.

Sharon N, Eshdat Y, Silverblatt FJ, Ofek I. 1981. Bacterial adherence to cell surface sugars. CIBA Foundation Symposium Proceeding 80: 119-141.

Strauss JS, Kligman AM, Pochi PE. 1962. The effect of androgens and estrogens on human sebaceous glands. J Invest Dermatol 39(2): 139155.

Tenno M, Ohtsubo K, Hagen FK, Ditto D, Zarbock A, Schaerli P, von Andrian UH, Ley K, Le D, Tabak LA, Marth JD. 2007. Initiation of protein o glycosylation by the polypeptide GalNAcT-1 in vascular biology and humoral immunity. Mol Cell Biol 27(24): 8783-8796.

Thody AJ, Shuster S. 1989. Control and function of sebaceous glands. Physiol Rev 69: 383-416

Tsukise A, Meyer W, Ikeda T. 1985. Carbohydrate histochemical investigation in the scrotal skin of the common American opossum (Didelphis marsupialis L.). Cell Mol Biol 31: 357-364.

Tsukise A, Meyer W. 1983. Histochemistry of complex carbohydrates in the hairy skin of the domestic pig. Histochem J 13: 845-860.

Van Weers DJ. 1979. Notes on southeast Asian porcupines (Hystricidae, Rodentia) IV. On the taxonomy of the subgenus Acanthion F. Cuvier. Beaufortia 29(356): 215-272.

Van Weers DJ. 1983. Specific distinction in old world porcupines. Der Zoologische Garten 53: 226-232.

Wollina U, Schaarschmidt H, Hipler C, Knopf B. 1989. Distribution of glycoconjugates in human skin appendages. Acta Histochem 87: 8793.

Yasui T, Tsukise A, Nara T, Kuwahara Y, Meyer W. 2006. Morphological, histochemical and immunohistochemical characterization of secretory production of the ciliary glands in the porcine eyelid. Eur J Histochem 50(2): 99-108.

Zherebtsova OV. 2000. Spiny cover and defence strategy of mammals. Proc Zool Inst RAS 286: 168-174. 